\title{
EFL Materials Development Based on Project Based Learning for Vocational High School
}

\author{
Arik Susanti \\ English Department \\ Universitas Negeri Surabaya \\ Indonesia \\ ariksusanti@unesa.ac.id
}

\author{
Anis Trisusana \\ English Department \\ Universitas Negeri Surabaya \\ Indonesia \\ anistrisusana@unesa.ac.id
}

\begin{abstract}
The purposes of the research were to know students' needs in learning English and to describe the process of developing EFL materials based on Project Based Learning (PjBL). It will provide English materials that are suitable for the learning objective and consider the learners' needs in studying English. Moreover, PjBL can motivate students to acquire knowledge using discussion, and data collection to finish the project. PjBL encourage the students to study that require authentic materials so that they are able to use language to communicate. This study was blended method (qualitative and quantitative approach) in which the participants were some students and English teachers in East Java Vocational High Schools. The data were gained through interview, questionnaire and classroom observation. The data were analyzed quantitatively using frequency and percentage, while the data from interview were transcribed and analyzed qualitatively. The results showed that the learners and the teachers responded positively towards the development of English supplementary materials for Vocational High School. The materials were developed by considering the result of their needs. Then, it was evaluated by the teachers and the result was categorized as good. In the future, it is hoped that the supplementary materials can be implemented in Vocational High School.
\end{abstract}

Keywords-English Materials Development; Project Based Learning; English for Specific Purposes

\section{INTRODUCTION}

An educational institution that provides learning in developing specific skills is vocational high school (SMK). Students are given an opportunity to develop their skill based on their interest. Moreover, they are expected to apply their knowledge and skills that are suitable with the their job fields. After they graduate from school, they are hoped to use their language to communicate professionally and fluently. Learners are also prepared to face the global economic challenges. It means that they must have soft skill to face the world's competition.

But, the fact shows that most learners have lack of English competence. They think that English is difficult and they have some problems when they are learning English. One of the problems is the use of textbook. Most of the teachers only use text book recommended by their principals and they do not use any supplementary material. Moreover, the English textbook used in Vocational High School does not give specific materials for the students. It is known that material is an essential part in the process of teaching learning. It can help learner improve their knowledge and skill. Moreover, it cal also facilitate them to study. It is known that a good material will bring good impacts to the learner's development during the learning process [1]. In addition, the materials should consider the learning needs and the characteristics of each study programs which has its special purposes (ESP). According to Hutchinson and Waters (1987), to meet the students' need, the teacher must create material that is in line with English for Specific Purposes. It can encourage the students to be creative and more focused. Moreover, the materials are related to their future and their needs. Therefore, the material development of Vocational English is highly needed in order to empower the students' skills.

Developing a good ELT material can be based on Project Based Learning (PjBL) as it can enable teachers to teach English more personalized, more varied, and more effectively [2]. PjBL also builds the students' literacy and creative thinking skills [3]. Students practice from low order thinking to high order thinking. It means they try to develop their domain of knowledge [4]. Project Based Learning does not only need reading but also writing so that it will improve the students' literacy skill 5]. Related to literacy skills, students focus on the learning by doing rather than being explicitly taught. Here, they are given chance to practice their language skills and finallly their literacy skills. Additionally, the students will learn how to make cooperation, create a product and present or communicate a product in their group so that their critical thinking abilities and creativity will develop. They can also be able to work effectively in their group [6][7]. Students practice to speak their English in every aspect that are suitable with their profession. They can also learn how to discuss their work with other people. Therefore, students appreciate that they have learn something that has value to the situation of real life in their daily contexts [8].

Based on the background of the study, the aims of the research are to investigate the students' needs in learning English and to describe the process of developing EFL materials based on PjBL for vocational high school.

\section{RESEARCH METHOD}

The purposes of the research are to investigate the students' needs in learning English and describe the process of developing EFL materials based on PjBL. To know the 
students' need, questionnaire were used to calculate the students' need, background knowledge of the content for the eleventh grade students, and their hope after they are learning English for vocational high school. Moreover, open ended interviews were conducted to English teachers to know the students' need. Next, the textbook analysis rubric was used to measure and determine the quality, the content, the design, the learning strategy, and the attractiveness of the teaching materials used in vocational school. After knowing the students' needs, the researcher tried to design EFL supplementary material based on $\mathrm{PjBL}$. The procedure in designing the EFL textbook based on PjBL can be seen in the following diagram [9].

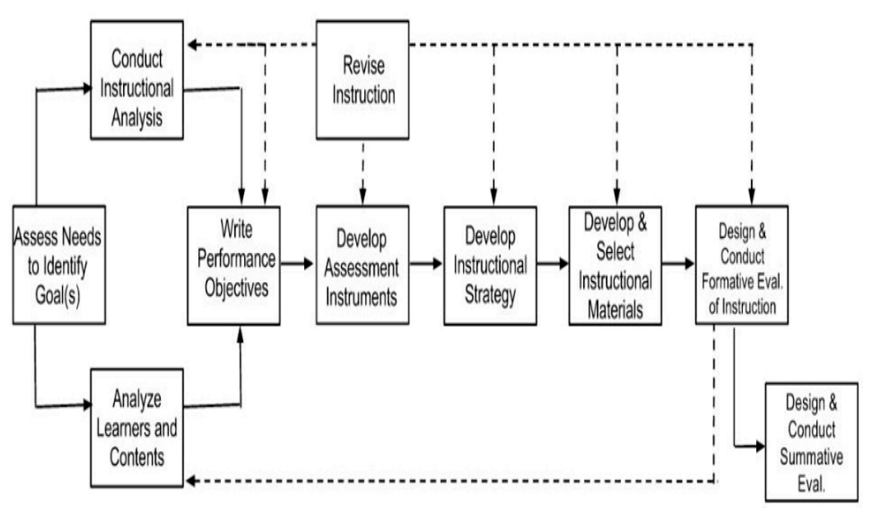

FIGURE I. THE FLOWCHART OF DESIGNING EFL TEXTBOOK

Data analysis was conducted by applying qualitative and quantitative methods. The data taken from the questionnaires were analyzed quantitatively, and the data resulted from observation, document, and interviews were analyzed qualitatively

\section{FINDINGS AND DISCUSSION}

\section{A. The results of students' questionnaire}

The functions of the needs analysis are to describe the students' preferences on theme, components of input, vocabulary and grammar, learner's role, teacher's role and setting of learning. The first description is about the theme, as indicated in Table 1. The table below shows the theme that the students want to be learned.

TABLE I. Themes

\begin{tabular}{|c|l|c|}
\hline No & \multicolumn{1}{|c|}{ Topic } & Percentage \\
\hline 1 & A theme of the work field & $34 \%$ \\
\hline 2 & A theme of their activity & $33 \%$ \\
\hline 3 & A theme of school environment & $11 \%$ \\
\hline 4 & A theme of daily life & $22 \%$ \\
\hline
\end{tabular}

It can be seen from Table 1 that the topics that students preferred to have were topics related to world of work $(34 \%)$, topics about their activity (33\%), and topics of daily life $(22 \%)$. Only a few of them $(6 \%)$ were engaged to the topics related to school environment
The next description is about the components of input that students prefer to have in English teaching and learning. It consists of four skills, namely, listening, reading, writing, and speaking. The following table shows the English skills preferred by the students.

TABLE II THE ASPECT OF INPUT ACTIVITY

\begin{tabular}{|c|c|c|}
\hline No & Activity & Percentage \\
\hline \multirow[t]{6}{*}{1.} & Listening Activity & \\
\hline & a. Filling the blanks due to the oral text & $26 \%$ \\
\hline & b. Answering the questions based on oral text & $24 \%$ \\
\hline & $\begin{array}{l}\text { c. Write the information in details based on oral } \\
\text { text }\end{array}$ & $6 \%$ \\
\hline & $\begin{array}{l}\text { d. dentifying expressions in the dialogue based } \\
\text { on oral text }\end{array}$ & $22 \%$ \\
\hline & $\begin{array}{l}\text { e. Deciding true or false on the provided } \\
\text { statements based on oral text }\end{array}$ & $22 \%$ \\
\hline \multirow[t]{4}{*}{2.} & Speaking Activity & \\
\hline & a. Role play & $52 \%$ \\
\hline & b. Presenting topic & $22 \%$ \\
\hline & c. Discussion about a topic & $26 \%$ \\
\hline \multirow[t]{5}{*}{3.} & Writing Activity & \\
\hline & a. Rewrite the paragraph & $52 \%$ \\
\hline & $\begin{array}{l}\text { b. Complete the missing words in the form of } \\
\text { paragraph }\end{array}$ & $12 \%$ \\
\hline & $\begin{array}{l}\text { c. Rearranged the jumbled sentences into a } \\
\text { good paragraph }\end{array}$ & $26 \%$ \\
\hline & d. Creating a composition & $10 \%$ \\
\hline \multirow[t]{9}{*}{4.} & Reading Activity & \\
\hline & a. Reading aloud & $32 \%$ \\
\hline & b. Reading and answer the questions & $18 \%$ \\
\hline & c. Summarizing & $10 \%$ \\
\hline & d. Finding the synonym and antonym & $10 \%$ \\
\hline & e. Finding the main idea & $15 \%$ \\
\hline & f. Finding the implied meaning & $5 \%$ \\
\hline & g. Finding the explicit meaning & $8 \%$ \\
\hline & h. Finding the detail information & $12 \%$ \\
\hline
\end{tabular}

Table II shows a dialog in the form of oral text $(26 \%)$ and filling the blanks due to oral text $(22 \%)$ became the favourite activity that the students liked most in the process of listening skill. In speaking skill, more than half of students $(52 \%)$ preferred to have role play as an activity to practice their speaking fluency. For the activity in writing, 52\% students enjoyed the activity of rewriting a paragraph. In reading activity, read aloud was the most favorite activity (32\%).

Related to vocabulary and grammar, the most preference activity is to get lists of new words from the text and find out their meanings in the dictionary $(51 \%)$. Meanwhile, $39 \%$ of the students' favorite activity is to write sentences as the given 
examples. Moreover, activity about correcting the mistakes is only answered by $28 \%$ students. The least favorite activity was to identify the mistakes in the sentence $(25 \%)$.

The next result is about learners' and teacher's role. It is known that $36 \%$ of the learners prefer to be responsive participant than to be performer in the classroom (33\%). Most of the students expected that the teacher should be the facilitator in the classroom $(32 \%)$. The teacher should guide them when they wanted to finish their project. They also hoped that the teacher must monitor and control them during they worked in their group. Related to the teacher role as a motivator, only $31 \%$ of the students hoped that their teacher would be the motivator.

More than fifty percent of the students (55\%) enjoyed to study in the classroom and they wanted to finish their project in group. They could practice their language in their daily life. $24 \%$ of the students chose to work individually. And only $21 \%$ of them preferred to work in pairs.

\section{B. Description of Interview Result}

From the results of the English teacher interviews, the teachers agreed that the English materials for vocational high school should be in line with their study program. In their opinion, vocational high school students would be able to reach the goal of English learning when the students had and got materials that were suitable with their department. In fact, the government implemented the same syllabus and teaching materials for senior high school and vocational high school. The government thought that the students 'level in senior high school and vocational were the same. Therefore, both of them were given the same materials. But, the fact was not like that. The students in vocational high school and senior high school have different level and motivation. Most of the students in SMK wanted to work after they graduated from school. It meant that they need supplementary material. It is also supported by the teachers that all of the English teachers wanted to have English supplementary materials for Vocational high school to meet the students' needs and to motivate them when they would study English. It also guides them to be creative people. Moreover, the supplementary materials should consist of literacy skills, HOTS and creative skills.

\section{Description of Analysing an English textbook materials}

The interview results also showed that English book that is published by the government was not used by English teachers who are teaching in SMK. They thought that English book was was still in the form of soft file. It was quite difficult to be implemented since only half of the students have computer. Because of that, they preferred to use the commercial books which were recommended by their principals. They thought commercial books are completed by learning tools such as syllabus, lesson plan, audio recording and assessment. The teachers did not need to design and create the new lesson plan and they could be ready to teach students. However, the commercial books lacked of its contextualization, for example they did not present local culture and wisdom appropriately. As a consequent, it would affect the students' motivation to learn English. They did not like to read since they could not imagine the context. Finally they were not able to communicate using English. They did not have enough confidence in speaking
English, listening news or watching movies, reading books, and writing simple or long sentences or writing paragraph. Finally, most of the students did not reach the English competence; their competences of English skills were still low.

After clarifying the teachers' interview, it would be discussed. The results of the textbook analysis. It showed that the concept organization of the book used in the classroom was quite good. However, there are several parts, especially in the enrichment parts, which were irrelevant to the 2013 curriculum for the eleventh grade of Vocational High School. For example, there were explanation and exercises about narrative text which was not categorized as a basic competence for the eleventh grade students. Related to the material evaluation, the materials implemented in the classroom was sufficient in considering cognitive, affective, and psychomotor domain. Yet, several assessments needed to be added. In addition, the materials were less relevant to support literacy skill. More texts and exercises in the parts of analytical exposition, explanation, and writing personal business letter were required in order to motivate the students to read and write.

\section{Designing The Materials}

There were several steps in designing English supplementary for vocational high school. The first, it was chosen the basic competences. After that, it was defined the learning objectives. It is known that the function of learning objectives to decide the learning goals, develop the materials.

The next step was creating the lesson plans consisting of learning objectives, learning goals, kinds of materials, media, learning activities, and assessment. To construct the assessment, it was based on the learning goal so that it consisted of cognitive test and performance test. Then, designing learning material based on project. Moreover, it was also depended on learning goals and students' needs. It was hoped that the students would be able to implement and use English properly.

In designing vocational English supplementary materials based on $\mathrm{PjBL}$, there were 5 stages implemented during the process. The implementation of the stages was to make the students easier in understanding the material. The first stage was selecting topic/project. In this stage, the teacher motivated the students to be active in classroom observation and discussion. The teacher asked the students to observe the presented teaching materials and express their ideas in the form of classroom discussion. During this phase, the teacher also gave a brief explanation that the students needed and encouraged them to practice their English in the process of teaching learning. At the end of this stage, the students in groups decided their projects. After selecting the project, the next stage was making plan. In this stage, the students and teacher made agreement about the project that would be constructed. There were many activities that the students must do. For example to know the concept of transactional text, the students must implement role play to understand it. Then, they must work in group to find the data related to finish their project. In this case, the students learned how to be responsible and collaborative each others. After that, they must arrange the schedule to finish their project. They, of course, have communicated during completing their project. Here, the 
students must behave as if they were in real work. They conduct the process of teaching learning by practice. It could be seen that, there are various methods that can be implemented in this step which made the students practice their English frequently. The methods are: (a) matching, the learners were asked to match words and their definitions; (b) completing, the learners were asked to complete a sentence or give explanation about pictures; (c) asking and answering, the learners were asked to answer some questions; (d) performance work, the learners have practiced the exercises based on the materials; (e) drilling, the learners have imitated and practiced for answering questions orally and write their description in simple writing.

The third stage in the process of designing vocational English supplementary materials based on $\mathrm{PjBL}$ was doing research. In the stage, the students have been tried how to collect information about the language skills and the strategies to finish their project. The students' ability and level had become the teacher's focus to prepare instructional activities to get the information-gathering tasks. In doing research step, the teacher provided many methods such as discussion, debates, situational role play, description, quizzes and games. In this activity the learners were given the opportunity to argue in accordance with situational phenomenon that was happening in their society. They were also given the opportunity to discuss the process of completing their project. In this phase, they learned how to express and clarify their ideas if they had different opinion. All of these activities were covered in small group discussion. Moreover, the learners were given a certain situation or case to create a project. All students were also involved in a variety of project or particular case that existed in the community. Finally, sharing results was the last step in which the students presented their final product. They had to present their project in front of the class, while other groups paid attention to the presentation and gave comments. During the project, the students reflected not only the competences of learning material but also the acquisition of English skills. Then, the students' presentation and performance would be given feedbacks or some comments by teacher. It included their language, cooperation, responsibility and their content learning. Moreover, recommendations have also been given to to enhance similar projects in the future. It made the students improve their critical thinking. Besides, the students learned how to present their ideas, communicate confidently, and behaved as if they had been in real situation.

\section{E. Discussion}

In the process of teaching learning, materials have a vital role. One example of learning materials is text book. It has been known that text book plays an important part in learners' achievement or failure. However, designing good learning materials needed hard works to attract the readers to read and use the language. Besides, the author must know the students' needs. It is in line with the theory of ESP proposed by Hutchinson and Waters [2] that states developing effective and good learning materials should be based on the students' need, text book analysis and the teachers' response. It will make the the materials meet the students' interests, needs and lacks. Finally they were to motivated to read to encourage their critical thinking and creativity.
In the development of vocational English supplementary materials based on PjBL, the materials consisted of 8 chapters completed with explanation and exercises related to the topics. The design of the materials was developed using PjBL approach and focused to help the learners acquire the learning content and language skills during the process of teaching and learning. The materials developed were designed based on the 2013 curriculum in which all the skills were integrated as it could empower the students' literacy and creativity. In addition, the difficulty of developed material was relevant to the students' level of competences.

The result of the evaluation was overall good. The appearance of EFL materials was quite interesting. Moreover, the instructions were easy enough to be comprehended, and the content of textbook could guide the students to comprehend and understand it well. However, there were some parts of the supplementary materials that needed to be revised. Some exercises had similar sentences in a chapter, thus the sentences should be revised. Moreover, it was suggested to provide more tasks that could help learners become more active, creative and independent. In the part of assessment, it were described as good since it provided real situation that could motivate the students to create a certain project. It also encouraged the students to read many sources during the process of project completion. This led them to be more creative and independent.

\section{CONCLUSION}

To develop English supplementary materials for vocational high school using $\mathrm{PjBL}$ needs to consider several aspects that are the students' needs, the conformity to the curriculum, and the students' majors. Designing the materials should be based on the results of student needs analysis in order to make the students study English effectively. Besides, it must conform to the curriculum. Referring to the 2013 curriculum, the materials developed using PjBL approach improves all language skills that are integrated (listening, reading, writing, speaking). The developed materials also have to be related to their working situation in the future. It means the development of vocational English materials must be based on ESP. It is to help the students acquire the English competences and use them to get good careers in the future. It is recommended that English teachers should teach vocational English more creative and innovative to improve the students' competences. In order to achieve the goals, it is suggested to create EFL supplementary materials that are appropriate to students' majors, needs and their goals. The developed EFL as additional materials can facilitate and motivate the students to learn English directly or indirectly.

\section{REFERENCES}

[1] B. Tomlinson. Materials Development in Language Teaching. Cambridge: Cambridge University Press, 1998.

[2] T. Hutchinson \& A. Waters. English for Specific Purpose: A Learning Centred Approach. New York: Cambridge University Press, 1987.

[3] J. Ravitz. Project based learning as a catalyst in reforming high schools. Paper presented at Annual Meetings of the American Educational Research Association. New York, NY, 2008. 
[4] O. Akinoglu. Assessment of the inquiry-based project application in science education upon Turkish science teachers' perspectives. Education. vol 129, pp. 202-215, 2008.

[5] M. M. Grant \& R. M. Branch. Project-based learning in a middle school: Tracing abilities through the artifacts of learning. Jour of Research on Tech in Edu, vol 38, pp. 65-98, 2005.

[6] L. Darling-Hammond. Benchmarking Learning Systems: Student Performance Assessment in International Context. Stanford, CA: Stanford Center for Opportunity Policy in Education, 2010.

[7] M. Neo \& T. K. Neo. Engaging students in multimedia-mediated constructivist learning - Students' perceptions. Edu. Tech. \& Society, vol 12 , pp. $254-266,2009$.

[8] S. Wurdinger, J. Haar, R. Hugg, \& J. Bezon. A qualitative study using project-based learning in a mainstream middle school. Improving Schools, vol 10, pp. 150-161, 2007.
[9] K. Gubacs. Project-based learning: A student-centered approach to integrating technology into physical education teacher education. Journal of Physical Education, Recreation and Dance, vol 75, pp. 33-37, 2004.

[10] W. Dick, L. Carey, \& J. O. Carey. The systematic design of instruction. Pearson, New York, 2005

[11] C. Lopez-Mayan \& C. Nicodemo. Vocational High School or Vocational College? Comparing the Transitions from School to Work. IZA Discussion Paper, 34, 2012.

[12] B. Paltridge \& S. Starfield. The Handbook of English for Specific Purposes. UK: John Wiley \& Sons, Inc, 2013.

[13] Y. Zhang. A Practical English Teaching Mode of Vocational Education: Induction-Interaction Learning Community. English Language Teaching, vol 1, pp. 5, 2008. 